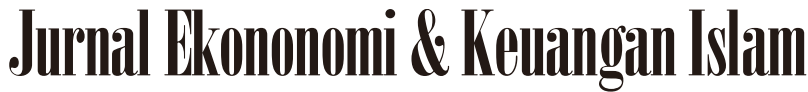

\author{
Available at http://journal.uii.ac.id/index.php/jeki
}

\section{Pengaruh pembiayaan mudharabah, musyarakah dan murabahah terhadap profitabilitas BPRS di Indonesia periode 2012-2015}

\author{
Rivalah Anjani* dan Maulidiyah Indira Hasmarani \\ Fakultas Ekonomi dan Bisnis, Universitas Muhammadiyah Surakarta \\ *Corresponden Author. E-mail: anjani.rivalah@gmail.com
}

\begin{tabular}{l} 
Keywords: \\
Mudaraba, Musharaka, \\
Murabaha and Profitability \\
(ROE) \\
\hline DOI: \\
10.20885/JEKI.vol2.iss2.art5 \\
\hline
\end{tabular}

10.20885/JEKI.vol2.iss2.art5

\begin{abstract}
This study aims to analyze the effect of Mudaraba financing, Musharaka, and Murabaha to the level of profitability of BPRS in Indonesia period 2012 to 2015 by using ratios Return On Equity (ROE) simultaneously and partially. The sample used in this study were 64 data includes 4 BPRS by using the quarterly financial statements I to IV for 4 years period. Methods of data analysis used in this research is panel data regression with Eviews program. The results of this study indicate that the Mudaraba financing is partially a significant negative effect on the level of ROE, in contrast to musyarakah partially positive and significant impact on the level of ROE. Murabaha financing does not affect significantly the level of ROE.
\end{abstract}

\begin{abstract}
Abstrak
Penelitian ini bertujuan untuk menganalisis pengaruh pembiayaan Mudaraba, Musharaka, dan Murabahah terhadap tingkat profitabilitas BPRS di Indonesia periode 2012 sampai 2015 dengan menggunakan rasio Return On Equity (ROE) secara simultan dan parsial. Sampel yang digunakan dalam penelitian ini adalah 64 data yang mencakup 4 BPRS dengan menggunakan laporan keuangan kuartalan I sampai IV selama 4 tahun. Metode analisis data yang digunakan dalam penelitian ini adalah regresi data panel dengan program Eviews. Hasil penelitian ini menunjukkan bahwa pembiayaan Mudaraba secara parsial merupakan efek negatif yang signifikan terhadap tingkat ROE, berbeda dengan musyarakah yang secara parsial berpengaruh positif dan signifikan terhadap tingkat ROE. Pembiayaan Murabahah tidak berpengaruh secara signifikan terhadap tingkat ROE.
\end{abstract}

\section{Pendahuluan}

Perbankan di Indonesia mengalami perkembangan yang sangat pesat seiring permintaan dan pemikiran masyarakat. Bank terbagi dua jenis, yaitu bank syariah dan bank konvensional. Perbedaan antara bank syariah dan bank konvensional terletak pada sistem operasionalnya. Bank syariah menggunakan sistem bagi hasil sedangkan bank konvensional menggunakan sistem riba. Adapun jumlah perbankan syariah di Indonesia adalah 195 bank yang terdiri dari BUS (Bank Umum Syariah), UUS (Unit Usaha Syariah) dan BPRS (Bank Pembiayaan Rakyat Syariah) (OJK, 2016). Banyaknya kritik terhadap bank konvensional karena karakteristiknya yang masih terdapat unsur riba, judi (maysir), ketidakpastian (gharar), dan bathil maka perbankan syariah menjadi sebuah alternatif bagi praktek perbankan konvensional sehingga perbankan syariah tumbuh semakin meningkat (Umam, 2011).

Semakin meningkatnya aktivitas ekonomi masyarakat, peranan lembaga keuangan pun turut meningkat. Di antara beberapa perbankan syariah di Indonesia, BPRS (Bank Pembiayaan Rakyat Syariah) salah satu perbankan syariah yang menjadi pilihan masyarakat untuk mengembangkan usaha mikro, kecil dan menengah serta memberikan pembiayaan terhadap masyarakat kecil menengah ke bawah. Perkembangan industri BPR dan BPR Syariah yang terus mengalami peningkatan secara pesat berdasarkan data OJK hingga bulan Desember 2015, ada 163 buah dengan jaringan 433 kantor yang tersebar dan beroperasi di seluruh wilayah Indonesia. Provinsi Jawa Timur tercatat sebagai wilayah yang paling banyak memiliki BPRS sebanyak 29 bank. Hal ini menunjukkan bahwa jangkauan pelayanan BPRS semakin luas dan keberadaannya semakin dibutuhkan oleh masyarakat.

Kehadiran BPR melalui penyaluran kredit bagi masyarakat menengah ke bawah yang umumnya berorienttasi sebgai pelaku Usaha Mikro Kecil Menengah (UMKM) menjadi sangat penting, karena mayoritas pelaku usaha di Indonesia merupakan pelaku UMKM. BPR menawarkan solusi untuk mengatasi hambatan permasalahan permodalan kepada pelaku usaha informal untuk mengembangkan usahanya sehingga BPR dan BPRS menjadi sangat berguna bagi pengembangan UMKM di Indonesia. Bila penyaluran kredit BPRS yang diberikan kepada pelaku UMKM terus menurun, maka diprediksikan upaya guna mendorong pertumbuhan 
ekonomi akan menjadi terhambat. Semua lembaga keuangan memiliki beberapa jasa yang ditawarkan kepada masyarakat agar masyarakat minat memakai jasanya karena semakin banyak masyarakat memakai jasa suatu lembaga keuangan secara tidak langsung masyarakat pun ikut berperan dalam pertumbuhan ekonomi. Begitupun halnya dengan BPRS, menawarkan jasa dengan sistem pembiayaan syariah(Yuliarmi \& Yoga, 2013). Sistem pembiayaan syariah yang ditawarkan BPRS berupa akad mudharabah, musyarakah, murabahah, salam, dan ishtisna. Tetapi yang lebih sering masyarakat menggunakan sistem pembiayaan dengan akad mudharabah, musyarakah dan jual beli seperti murabahah.

Mudharabah adalah akad diantara dua belah pihak, dimana pihak yang satu menyerahkan modal dan pihak lainnya memberdayakan modal tersebut untuk usaha, serta keuntungan yang diperoleh dibagi bersama sesuai porsi bagi hasil disepakati pada saat akad (Janwari, 2015). Selanjutnya akad musyarakah adalah akad antara dua pihak atau lebih untuk berserikat dalam hal modal dan keuntungan yang diperoleh. Pembiayaan musyarakah pada perbankan syariah adalah penyertaan modal yang diberikan bank syariah terhadap nasabah yang telah memiliki sebagian modal. Sedangkan akad murabahah adalah jual beli barang dengan alat tukar disertai tambahan yang telah ditentukan (resale with a stated profit). Pembiayaan murabahah pada perbankan syariah yakni bank syariah bertindak sebagai penjual, sedangkan nasabah bertindak sebagai pembeli.

Bank Pembiayaan Rakyat Syariah sebelum UU Perbankan Syariah dikenal dengan Bank Perkreditan Rakyat Syariah. Bank Pembiayaan Rakyat Syariah (BPRS) juga merupakan lembaga intermediasi keuangan, akan tetapi tidak diperbolehkan melakukan kegiatan usaha dalam lalu lintas pembayaran. Undang - Undang Perbankan No. 10 tahun 1998 tentang perubahan undang-undang No. 7 tahun 1992 tentang perbankan, pasal 1 menyebutkan bahwa Bank Perkreditan Rakyat adalah bank yang melakukan kegiatan usaha secara konvensional atau berdasarkan prinsip syariah yang dalam kegiatannya tidak memberikan jasa dalam lalu lintas pembayaran (Kasmir, 2012). Jadi, Bank Perkreditan Rakyat Syariah dapat didefinisikan sebagai sebuah lembaga keuangan yang operasionalnya memakai prinsip-prinsip syariah.

Kegiatan usaha Bank Pembiayaan Rakyat Syariah menurut Undang-Undang No. 21 Tahun 2008 tentang Perbankan Syariah diatur dalam pasal 21, yaitu bahwa kegiatan usaha yang dapat dilakukan oleh BPRS meliputi: (1) menghimpun dana dari masyarakat dalam bentuk simpanan tabungan akad wadi'ah dan investasi berupa deposito, (2) menyalurkan dana kepada masyarakat dalam bentuk pembiayaan bagi hasil berdasarkan akad mudharabah atau musyarakah; pembiayaan berdasarkan akad murabahah, salam, atau istishna'; pembiayaan berdasarkan akad qardh; pembiayaan penyewaan barang bergerak atau tidak bergerak kepada nasabah berdasarkan akad ijarah atau sewa beli dalam bentuk ijarah muntahiya bittamlik; dan pengambilalihan utang berdasarkan akad hiwalah; (3) menempatkan dana bank syariah lain dalam bentuk titipan berdasarkan akad wadi'ah atau investasi berdasarkan akad mudharabah dan/atau akad lain yang tidak bertentangan dengan prinsip syariah; (4) memindahkan uang, baik untuk kepentingan sendiri maupun untuk kepentingan nasabah melalui rekening Bank Pembiayaan Rakyat Syariah yang ada di Bank Umum Syariah, Bank Konvensional, dan UUS; (5) menyediakan produk atau melakukan kegiatan usaha Bank Syariah lainnya yang sesuai dengan prinsip syariah berdasarkan persetujuan Bank Indonesia.

Pembiayaan adalah penyediaan dana atau tagihan/piutang yang dapat dipersamakan dengan itu berupa transaksi investasi, transaksi sewa, transaksi jual beli, transaksi pinjam meminjam dan transaksi multijasa berdasarkan persetujuan atau kesepakatan antara bank dengan nasabah pembiayaan yang mewajibkan nasabah pembiayaan untuk melunasi hutang/kewajiabannya dan/atau menyelesaikan investasi mudharabah dan/atau musyarakah dan hasil pengelolaannya sesuai dengan akad (Umam, 2011). Mudharabah adalah akad diantara dua belah pihak, dimana pihak yang satu menyerahkan modal dan pihak lainnya memberdayakan modal tersebut untuk usaha, serta keuntungan yang diperoleh dibagi bersama sesuai porsi bagi hasil disepakati pada saat akad (Janwari, 2015). Implementasi pembiayaan mudharabah di perbankan syariah adalah pihak bank memberikan modal investasi atau modal kerja secara penuh (trusty financing), sedangkan nasabah menyediakan proyek atau usaha lengkap dengan manajemennya. Kemudian hasil keuntungan dan kerugian yang dialami nasabah dibagi atau ditanggung bersama antara bank dan nasabah dengan ketentuan sesuai kesepakatan bersama. Pada prinsipnya, rukun akad mudharabah terdiri dari: (a) Pihak yang berakad (subjek perjanjian) yaitu pemilik modal (Shahibul Maal) dan pengelola dana (Mudharib); (b) Objek yang diakadkan (objek perjanjian) seperti, besarnya modal yang ditanamkan atau diserahkan oleh bank kepada pengelola, jenis pekerjaan yang akan dilakukan oleh pengelola, dan besarnya pembagian keuntungan (nisbah) antara bank dan pengelola; (c) Akad (shighat) Harus dinyatakan mengenai kesepakatan semua pihak dalam melaksanakan perjanjian, yang berupa ijab dan qabul (Purnamasari \& Suswinarno, 2011). Secara umum mudharabah terbagi menjadi dua jenis yaitu: (1) Transaksi mudharabah muthlaqah adalah bentuk kerjasama antara shahibul maal dan mudharib yang cakupannya sangat luas dan tidak dibatasi oleh spesifikasi jenis usaha, waktu dan daerah bisnis; (2) Mudharabah muqayyadah adalah bentuk kerjasama dimana pihak pengelola dana (mudharib) dibatasi dengan batasan jenis usaha, waktu, atau tempat usaha (Antonio, 2011). Musyarakah adalah perjanjian kerja sama antara dua pihak atau lebih untuk melakukan usaha tertentu. Masing-masing pihak memeberikan kontribusi dana. Keuntungan atau kerugian akan 
ditanggung bersama sesuai proporsi yang telah disepakati. Pembiayaan musyarakah pada perbankan syariah adalah penyertaan modal yang diberikan bank syariah terhadap nasabah yang telah memiliki sebagian modal (Purnamasari \& Suswinarno, 2011). Murabahah (Janwari, 2015) sebagai bagian dari jual beli yang ada transparansi antara penjual dan pembeli dalam hal harga jual dan harga beli telah banyak diimplementasikan di lembaga keuangan syariah. Baik di Lembaga keuangan bank maupun di lembaga keuangan non-bank, murabahah lebih banyak digunakan dalam aspek pembiayaan. Manfaat yang akan diperoleh bagi bank dengan adanya pembiayaan murabahah ini yakni, bahwa secara prinsip merupakan saluran penyaluran dana bank dengan cepat dan mudah. Bank mendapatkan profit yaitu margin dari pembiayaan serta mendapatkan fee-based income (administrasi, komisi asuransi, dan komisi notaris).

Profitabilitas merupakan hasil bersih dari sejumlah kebijakan dan keputusan perusahaan (Oktaviana, 2012). Bagaimana perusahaan menggunakan seluruh modal yang dimiliki untuk mendapatkan laba (keuntungan) merupakan cerminan kemampuan perusahaan menghasilkan laba (keuntungan). Rasio profitabilitas mengukur seberapa besar kemampuan perusahaan dalam menghasilkan keuntungan. Tanpa adanya keuntungan (profit), maka akan sulit bagi perusahaan untuk menarik modal dari luar. Dalam melakukan analisis perusahaan, di samping melihat laporan keuangan perusahaan, juga dapat dialakukan dengan menggunakan analisis laporan keuangan.

Return on Equity merupakan suatu pengukuran dan penghasilan yang tersedia bagi para pemihak maupun perusahaan (baik pemegang saham biasa maupun saham preferen) atas modal yang mereka investasikan di dalam perusahaan (Oktaviana, 2012). Rasio ini membandingkan antara laba bersih dengan modal, dimana disajikan dengan presentase. Rasio ini menunjukkan efisiensi penggunaan modal sendiri. Semakin tinggi return atau penghasilan yang diperoleh semakin baik keadaan perusahaan. Kekurangannya ROE adalah bahwa bank dengan tingkat yang lebih rendah dari modal akan menghasilkan rasio yang lebih tinggi (Davydenko, 2011). Namun seperti dalam penelitiannya Mokni dan Houssem yang juga menggunakan ROE sebagai ukuran profitabilitas alternatif. Itu adalah rasio net keuntungan untuk ekuitas dinyatakan sebagai persentase. Hal ini mencerminkan efisiensi bank manajemen dalam penggunaan dana pemegang saham (Mokni \& Rachdi, 2014).

Keuntungan yang diperoleh oleh bank bisa ditentukan oleh banyaknya pembiayaan yang disalurkan. Karena pembiayaan juga salah satu produk yang diminati oleh sebagian nasabah maka pembiayaan juga salah satu faktor yang mempengaruhi profitabilitas bank syariah. Profitabilitas bank syariah bisa diketahui meningkat atau menurunnya menggunakan pengukuran rasio keuangan, yaitu ROA (Return on Assets), ROE (Return on Equity). Peneliti menggunakan ROE sebagai alat ukur profitabilitas BPRS di Indonesia. Penelitian ini juga menggunakan Laporan Keuangan Triwulan 1 sampai 4 dari tahun 2012-2015 BPRS di Indonesia. Dari latar belakang tersebut, maka peneliti melakukan penelitian dengan judul "Pengaruh Pembiayaan Mudharabah, Musyarakarah, Dan Murabahah Terhadap Profitabilitas BPRS Di Indonesia Periode 2012-2015". Tujuan penelitian ini mengetahui pengaruh pembiayaan mudharabah, musyarakah, dan murabahah terhadap profitabilitas pada Bank Pembiayaan Rakyat Syariah (BPRS) di Indonesia secara parsial dan simultan.

Adapun penelitian yang terdahulu yang terkait dengan pembiayaan - pembiayaan pada bank syariah antara lain dilakukan oleh Faeruca Nindi Farotami dan R. Anastasia Endang Susilawati (2013) menganalisis tentang pembiayaan murabahah dan musyarakah secara simultan berpengaruh terhadap tingkat ROE. Pembiayaan murabahah secara parsial berpengaruh terhadap tingkat ROE. Pembiayaan musyarakah secara parsial tidak berpengaruh terhadap ROE. Penelitian selanjutnya oleh Qodriasari (2014) tentang mengetahui sejauh mana pengaruh pendapatan pembiayaan mudharabah, musyarakah, murabahah dan ijarah terhadap profititabilitas atau tingkat keuntungan bank syariah yang diukur dengan return on equity. Kesimpulan dari penelitian tersebut variabel pendapatan pembiayaan mudharabah, musyarakah, murabahah, dan ijarah memiliki pengaruh negatif signifikan terhadap profitabilitas keenam bank umum syariah sehingga dari keempat variabel tersebut tidak ada produk yang menjadi produk unggulan. Berdasarkan penelitian-penelitian terdahulu, penelitian yang akan dilakukan memiliki persamaan dan perbedaan. Persamaannya dengan penelitian terdahulu adalah beberapa variabel-variabel yang berpengaruh terhadap profitabilitas. Tetapi perbedaan terletak objek penelitian juga kurun waktu yang akan diteliti. Berdasarkan teori dan hasil penelitian terdahulu maka hipotesis sementara yang diajukan adalah H1: Terdapat pengaruh signifikan dalam pembiayaan mudharabah, musyarakah, dan murabahah terhadap profitabilitas BPRS secara parsial. H2: Terdapat pengaruh signifikan dalam pembiayaan mudharabah, musyarakah, dan murabahah terhadap profitabilitas BPRS secara simultan

\section{Metode Penelitian}

Data yang digunakan dalam penelitian ini adalah data panel yaitu berupa data triwulanan laporan keuangan dari Bank Pembiayaan Rakyat Syariah (BPRS) di Indonesia periode Maret 2012 - Desember 2015. Data yang digunakan adalah media website Bank Indonesia (www.bi.go.id) dan situs Otoritas Jasa Keuangan (www.ojk.go.id). Sumber penunjang lainnya berupa jurnal dan sumber-sumber lain. 
Populasi adalah kelompok elemen yang lengkap, yang biasanya berupa orang, objek, transaksi, atau kejadian di mana kita tertarik untuk mempelajarinya atau menjadi objek penelitian (Kuncoro, 2009). Populasi yang menjadi objek penelitian ini seluruh bank pembiayaan rakyat syariah yang ada di Indonesia selama kurun waktu 2012-2015. Sampel yang digunakan dalam penelitian ini non-probability sampling dengan metode purposive sampling. Non-probability sampling menthods atau pemilihan sampel secara tidak acak dimana probabilitas masing-masing anggota populasi tidak diketahui (Oktaviana, 2012).

Teknik penentuan sampel dalam penelitian ini adalah menggunakan purposive sampling dimana peneliti memilih sampel berdasarkan tujuan penelitian dan kesesuaian kriteria-kriteria yang telah ditetapkan oleh peneliti. Adapun kriteria-kriteria dipilihnya Bank Pembiayaan Syariah yang menjadi sampel dalam penelitian ini adalah:

1. Bank Pembiayaan Rakyat Syariah yang terdaftar di Bank Indonesia

2. Bank Pembiayaan Rakyat Syariah (BPRS) tersebut menerbitkan laporan keuangan triwulanan periode triwulan I 2012 sampai triwulan IV 2015 secara konsisten dan telah dipublikasikan di website Bank Indonesia.

3. Bank Pembiayaan Rakyat Syariah (BPRS) tersebut memiliki data yang dibutuhkan terkait variabel-variabel yang digunakan untuk penelitian selama periode 2012-2015.

Berikut penjabaran masing-masing sampel dalam penelitian ini.

Tabel 1. Kriteria Sampel Penelitian

\begin{tabular}{lc}
\hline \multicolumn{1}{c}{ Kriteria } & Jumlah \\
\hline Bank yang termasuk BPR Syariah di Indonesia & 163 \\
BPRS yang tidak memiliki data yang dibutuhkan terkait variabel- & 159 \\
variabel yang digunakan untuk penelitian selama tahun 2012-2015 & \\
\hline Total sampel & 4 \\
\hline Sumber: data sekunder yang diolah, 2016
\end{tabular}

Tabel 2. Data hasil pemilihan sampel

\begin{tabular}{lc}
\hline \multicolumn{1}{c}{ Keterangan } & Jumlah \\
\hline $\begin{array}{l}\text { Jumlah sampel } 4 \text { buah x } 4 \text { triwulan x } 4 \\
\text { tahun penelitian }\end{array}$ & 64 \\
\hline Total data yang diteliti & 64 \\
\hline Sumber: data sekunder yang diolah, 2016
\end{tabular}

Jumlah data yang menjadi sampel penelitian ini adalah 64 karena adanya penggabungan data time series dengan cross section yang disebut juga data panel (Utomo, 2014). Oleh karena itu, penelitian ini menggunakan aplikasi Eviews.

Analisis data dalam penelitian ini merupakan analisis kuantitatif yang dinyatakan dengan angka-angka dan perhitungan model statistik dengan pengolahan data data panel melalui program Eviews. Dalam penelitian ini, pengukuran pengaruh pembiayaan mudharabah, musyarakah, dan murabahah terhadap profitabilitas bank pembiayaan syariah di Indonesia akan diukur dengan metode PLS (Pooled Least Square) hasil replikasi dari penelitian Nor Jana Salim dkk dengan persamaan regresi sebagai berikut (Salim, Mustaffa, \& Jusoff, 2011):

$$
\pi(\mathrm{ROE}) \mathrm{i}=\beta 0 \mathrm{i}+\beta 1 \log \mathrm{X} 1 \mathrm{i}+\beta 2 \log \mathrm{X} 2 \mathrm{i}+\beta 3 \log \mathrm{X} 3 \mathrm{i}+\mathrm{ei}
$$

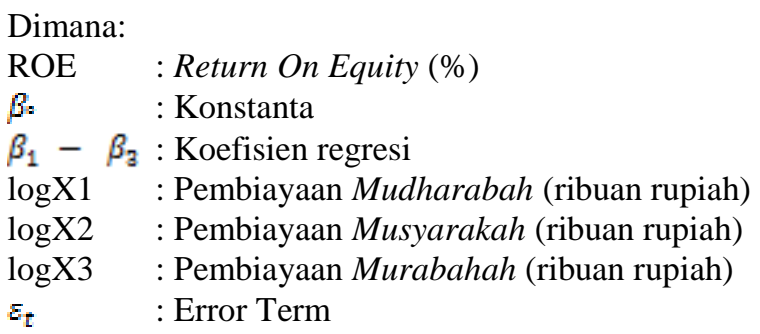

Berikut ini akan dijelaskan mengenai definisi operasional variabel yang akan digunakan dalam penelitian, yaitu: Profitabilitas (ROE), Profitabilitas merupakan kemampuan perusahaan menghasilkan laba. Laba tersebut diperoleh dari modal dan aktiva yang dimilikinya (Syamsudin, 2011). Keuntungan itu dapat dilihat dari tingkat profitabilitas yang diukur menggunakan rasio keuangan. Rasio keuangan yang digunakan adalah rasio Return On Equity (ROE) yaitu tingkat pengembalian modal bank tersebut. ROE dapat mengetahui kemampuan bank dalam mengelola modal yang dimilikinya untuk pembiayaan mudharabah, musyarakah, dan 
murabahah (Inti Dwi Permata, Yaningwati, \& Z.a, 2014). Rasio ini juga merupakan ukuran kepemilikan bersama dari pemilik bank tersebut.

1) Pembiayaan Mudharabah (X1)

Pembiayaan Mudharabah adalah pembiayaan yang dalam penyerahan modal uang kepada orang yang berniaga mendapatkan presentase keuntungan (Ascarya, 2007) .

2) Pembiayaan Musyarakah (X2)

Pembiayaan Musyarakah dalam Fatwa Nomor 08/DSN-MUI/IV/2000 adalah bahwa pembiayaan yang berdasarkan akad kerja sama antara kedua belah pihak atau lebih untuk usaha tertentu sesuai dengan nisbah yang disepakati dan risiko ditanggung bersama.

3) Pembiayaan Murabahah (X3)

Pembiayaan Murabahah dalam perbankan syariah yaitu akad jual beli antara bank dengan nasabah dimana bank membeli barang yang diperlukan nasabah kemudian menjualnya kepada nasabah tersebut dengan harga pokok ditambah margin keuntungan yang disepakati oleh bank dan nasabah (Reinissa, 2015).

Penelitian ini menggunakan analisis regresi data panel yang terdiri dari beberapa tahapan, antara lain:

a. Penentuan Model Estimasi

Data dalam penelitian ini akan dianalisis dengan menggunakan tiga model estimasi yaitu

1) Common Effect Model atau Pooled Least Square (PLS) merupakan pendekatan model data panel yang paling sederhana karena hanya mengkombinasikan data time series dan cross section, model persamaan regresinya adalah (Winarno, 2009) :

$$
\text { Yit }=\beta_{0}+\beta_{1} X_{1 i t}+\beta_{2} X_{2 i t}+\beta_{3} X_{3 i t}+e_{i t}
$$

2) Fixed Effect Model (FEM) Model ini mengasumsikan bahwa perbedaan antar individu dapat diakomodasi dari perbedaan intersepnya. Dalam membedakan intersepnya dapat digunakan peubah dummy sehingga model estimasi ini sering juga disebut dengan teknik Least Squares Dummy Variable (LSDV). Model Fixed Effect dengan teknik variabel dummy dapat ditulis sebagai berikut (Winarno, 2009):

$$
Y_{i t}=\beta_{0}+\beta_{1} X_{1 i t}+\beta_{2} X_{2 i t}+\beta_{3} X_{3 i t}+\beta_{4} X_{4 i t}+\beta_{5} d_{1 i t}+\beta_{6} d_{2 i t}+\beta_{7} d_{3 i t}+\ldots+\beta_{n} d_{n i t}+e_{i t} .
$$

3) Random Effect Model (REM) Model ini akan mengestimasi data panel dimana variabel gangguan mungkin saling berhubungan antar waktu dan antar individu. Keuntungan menggunakan model Random Effect yakni menghilangkan heteroskedastisitas. Penulisan konstanta dalam model Random Effect tidak lagi tetap tetapi bersifat random sehingga dapat ditulis dengan persmaan sebagai berikut (Winarno, 2009):

$$
\text { Yit }=\beta_{0}+\beta_{1} X_{1 i t}+\beta_{2} X_{2 i t}+\beta_{3} X_{3 i t}+e_{i t}+\mu_{i}
$$

b. Penentuan Metode Estimasi

Secara formal terdapat tiga pengujian yang dapat digunakan, yaitu sebagai berikut

1) Uji Chow, Chow test adalah pengujian untuk menentukan model Common Effect atau Fixed Effect yang paling tepat digunakan dalam mengestimasi data panel dengan hasil H0: Pilih PLS, H1: Pilih FEM

2) Uji Hausman, Hausman test adalah pengujian statistik untuk memilih apakah model Fixed Effect atau Random Effect yang paling tepat digunakan dengan hasil H0: Pilih REM, H1: Pilih FEM

3) Uji Langrange Multiplier (LM) adalah uji untuk mengetahui apakah model Random Effect lebih baik daripada metode Common Effect (OLS) digunakan dengan hasil: H0: Pilih PLS, H1: Pilih REM

c. Uji Hipotesis

Untuk melakukan pengujian terhadap hipotesis-hipotesis yang diajukan, perlu digunakan analisis regresi melalui uji t maupun uji F. Tujuan digunakan analisis regresi adalah untuk mengetahui pengaruh variabelvariabel independen terhadap variabel dependen, baik secara parsial maupun secara simultan, serta mengetahui besarnya dominasi variabel-variabel independen terhadap variabel dependen. Metode pengujian terhadap hipotesa yang diajukan dilakukan dengan pengujian secara parsial dan pengujian secara simultan (Fidin, 2014). Uji F dikenal dengan uji serentak atau uji Model/Uji Anova, yaitu uji untuk melihat bagaimanakah pengaruh semua variabel bebasnya secara bersama-sama terhadap variabel terikatnya. Atau untuk menguji apakah model regresi yang kita buat baik/signifikan atau tidak baik/non signifikan. Untuk melihat $\mathrm{F}$ tabel dalam pengujian hipotesis pada model regresi, perlu menetukan derajat bebas atau degree of freedom (df). Hal in ditentukan dengan rumus df1 = k-1 dan df2 = n-k. Dimana $\mathrm{n}$ adalah banyaknyanya observasi kurun waktu data dan k adalah banyaknya variabel (dependen dan independen). Dalam pengujian ini dilakukan dengan tingkat kepercayaan $10 \%$ atau 0,10 . Kriteria pengujian: Jika nilai $\mathrm{F}$ hitung $\geq \mathrm{F}$ tabel 
atau probabilitas (signifikansi) $\leq 0,10(\alpha)$ maka Ho ditolak dan Ha diterima. Sebaliknya jika nilai F hitung $\leq$ F tabel atau probabilitas (signifikansi) $\geq 0,10(\alpha)$ maka Ho diterima dan Ha ditolak.

Uji t dikenal dengan uji parsial, yaitu untuk menguji bagaimana pengaruh masing-masing variabel bebasnya secara sendiri-sendiri terhadap variabel terikatnya. Uji ini dapat dilakukan dengan mambandingkan $t$ hitung dengan $\mathrm{t}$ tabel atau dengan melihat kolom signifikansi pada masing-masing $\mathrm{t}$ hitung.Untuk menguji apakah hipotesis yang diajukan diterima atau ditolak digunakan $\mathrm{t}$ statistik. Kriteria pengujiannya adalah Jika $-\mathrm{t}$ tabel $\leq \mathrm{t}$ hitung $\leq \mathrm{t}$ tabel maka Ho diterima dan Ha ditolak. Sebaliknya jika $\mathrm{t}$ hitung $\leq-\mathrm{t}$ tabel atau $\mathrm{t}$ hitung $\geq \mathrm{t}$ tabel maka Ho ditolak dan Ha diterima. Dalam uji t ini dilakukan derajat kebebasan (n-k-1) dimana $\mathrm{n}$ adalah jumlah koresponden dan $\mathrm{k}$ adalah jumlah variabel. Untuk tingkat keyakinan yang digunakan adalah $\alpha=10 \%$.

\section{Hasil dan Pembahasan}

Berdasarkan uji pemilihan model estimasi yang terpilih adalah Model Common Effect. Berikut hasil dari analisis Model Common Effect dapat dilihat di tabel 4.1

Tabel 4.1 Hasil Analisis Model Common Effect

\begin{tabular}{ccccc}
\hline Variabel & Koefisien Beta & T & Sig & Kesimpulan \\
\hline C & 484,4317 & 1,4020 & 0,1661 & - \\
Log X1 & -18.6813 & $-1,8855$ & 0,0642 & Signifikan negatif \\
Log X2 & 22,3160 & 1,9554 & 0,0552 & Signifikan positif \\
Log X3 & $-31,9110$ & $-1,2272$ & 0,2245 & Tidak signifikan \\
F & & 3,1616 & 0,0309 & Signifikan \\
R Squared & & & & 0,1365 \\
\hline
\end{tabular}

Sumber: Data diolah

\section{Hasil Uji Regresi Parsial (Uji t)}

Berdasarkan pengujian yang sebelumnya, pengujian statistik $\mathrm{t}$ ini menggunakan model common effect. Uji $\mathrm{t}$ ini bertujuan untuk menguji pengaruh pembiayaan Mudharabah, Musyarakah dan Murabahah terhadap profitabilitas pada tingkat signifikansi $\alpha=0,10$ secara parsial.

Menurut tabel 4.1, pengujian variabel pembiayaan Mudharabah (X1) terhadap Profitabilitas (ROE) dengan nilai t-statistik adalah sebesar $-1,8856$ dengan tingkat signifikansi (probabilitas) $=0,0642$. Oleh karena nilai profitabilitas kurang dari $\alpha=0,10$ maka variabel pembiayaan Mudharabah (X1) berpengaruh negatif dan signifikan terhadap profitabilitas pada tingkat $\alpha=0,10$.

Pengujian variabel pembiayaan Musyarakah (X2) terhadap ROE menghasilkan nilai t-statistik sebesar 1,9554 dengan tingkat signifikansi (profitabilitas) $=0,0552$. Berdasarkan nilai profitabilitas yang kurang dari $\alpha=$ 0,10 maka variabel pembiayaan Musyarakah (X2) berpengaruh positif dan signifikan terhadap ROE. Hasil estimasi menyatakan Musyarakah berpengaruh positif dan signifikan terhadap ROE BPR Syariah di Indonesia pada tingkat $\alpha=0,10$. Selanjutnya, pengujian variabel pembiayaan Murabahah (X3) terhadap ROE menghasilkan nilai statistik t sebesar $-1,2273$ dengan tingkat signifikansi (profitabilitas) $=0,2245$. Berdasarkan nilai profitabilitas lebih dari $\alpha=$ 0,10 maka variabel pembiayaan Murabahah (X3) tidak signifikan terhadap ROE. Dengan demikian, berdasarkan uji hipotesis yang dilakukan didapatkan hasil yaitu pembiayaan Murabahah tidak berpengaruh terhadap ROE pada tingkat $\alpha$ sampai dengan 0,10 . Jadi, hipotesis yang diajukan tidak terbukti.

Uji statistik $\mathrm{F}$ bertujuan untuk menunjukkan apakah semua variabel bebas dalam model mempunyai pengaruh secara simultan terhadap variabel terikat (dependen). Pengujian dilakukan dengan menggunakan significance level $0,10(\alpha=10 \%)$. Berdasarkan tabel 4.1 terlihat bahwa nilai F-statistic sebesar 3,1616 dengan tingkat signifikansi 0,0310 . Tingkat signifikansi yang kurang dari $\alpha=10 \%$ menunjukkan bahwa model tersebut eksis untuk digunakan. Koefisien Determinasi $\left(R^{2}\right)$ bertujuan untuk mengukur seberapa jauh kemampuan model dalam menerangkan variasi variabel dependen. Model regresi penelitian ini menggunakan lebih dari satu variabel independen sehingga penelitian menggunakan $R$-squared untuk mengetahui persentasi sumbangan pengaruh variabel independen secara serentak terhadap variabel dependen. Berdasarkan tabel 4.1 didapat nilai $R$-square adalah 0,1365 . Nilai ini berarti bahwa sebesar $13,65 \%$ variasi dari variabel dependen dapat dijelaskan oleh variasi dari variabel penentu dalam model, sedangkan sisanya dipengaruhi oleh variasi variabel lain di luar model.

\section{Interpretasi Ekonomi}

Berdasarkan hasil penelitian terhadap variabel Mudharabah diperoleh koefisien regresi sebesar -18,6813 dengan nilai signifikan sebesar 0,0642 . Nilai signifikan ini kurang dari tingkat signifikansi 0,10 berarti terdapat pengaruh negatif dan signifikan antara variabel Mudharabah (X1) dengan variabel ROE di BPR Syariah. Koefisien regresi X1 memiliki sebesar -18,6813, berarti jika Mudharabah (X1) naik satu persen, maka ROE akan turun sebesar 
18,6813\%. Sebaliknya jika Mudharabah (X1) turun satu persen, maka ROE akan naik sebesar 18,6813\%. Hal ini sesuai dengan penelitian Inti Dwi Permata (Inti Dwi Permata et al., 2014) bahwa pembiayaan mudharabah memberikan pengaruh negatif dan signifikan terhadap tingkat ROE. Pengaruh ini dapat dilihat dari besarnya penyertaan modal pihak bank pada pembiayaan mudharabah ini 100\%, sehingga juga menentukan besar keuntungan dari usaha tersebut.

Walaupun pembiayaan mudharabah berpengaruh negatif namun signifikan terhadap ROE BPR Syariah di Indonesia dikarenakan jumlah pembiayaan mudharabah terus mengalami peningkatan dari tahun ke tahunnya. Selain itu pembiayaan mudhrabah, bila dilihat dari perolehan keuntungannya pihak bank juga menerima tetapi bila mengalami kerugian maka pihak bank juga ikut menanggung resiko tersebut. Sesuai dengan teori menurut Purnamasari \& Siswarno (Purnamasari \& Suswinarno, 2011) bahwa ketentuan dalam akad Mudharabah adalah pemilik modal (shahibul mal) berhak atas keuntungan dan menanggung risiko.

Berdasarkan hasil penelitian terhadap variabel Musyarakah (X2) diperoleh koefisien regresi sebesar 22,3161 dengan nilai signifikan sebesar 0,0552. Nilai signifikansi yang lebih kecil dari tingkat signifikansi 0,10 berarti terdapat pengaruh positif dan signifikan antara variabel musyarakah dengan variabel ROE di BPR Syariah. Koefisien regresi X2 memiliki nilai sebesar 22,3161, berarti jika Musyarakah (X2) naik satu persen maka ROE akan naik sebesar 22,3161\%. Sebaliknya jika Musyarakah (X2) turun satu persen maka ROE turun sebesar 22,3161\%. Hasil penelitian ini sesuai dengan teori menurut Ilmi (Ilmi, 2002) dimana pembiayaan musyakarah kedua pihak ikut andil dalam penyertaan modal (equity participation), dan masing-masing dapat pula terjun langsung secara bersama-sama dalam proses manajeman. Bila mendapatkan keuntungan akan dibagi berdasarkan nisbah bagi hasil yang telah ditentukan di awal atas dasar kesepakatan kedua pihak secara proporsional tergantung besar kecilnya modal yang disertakan, namun bila merugi kedua pihak bersama-sama menanggung kerugian. Hal ini juga sesuai dengan penelitian Reinissa (Reinissa, 2015) bahwa pembiayaan musyarakah jauh lebih banyak digunakan dibandingkan dengan mudhrabah yang juga berpengaruh positif dan signifikan terhadap ROE.

Hasil penelitian terhadap variabel Murabahah (X3) diperoleh koefisien regresi sebesar -31,9110 dengan nilai signifikan sebesar 0,2245. Nilai signifikansi yang lebih besar dari tingkat signifikan 0,10 berarti tidak terdapat pengaruh signifikan dan negatif antara variabel Murabahah dengan variabel ROE di BPR Syariah. Hal ini sesuai dengan penelitian dari Ziqri (Ziqri, 2009) bahwa variabel pembiayaan murabahah tidak berpengaruh signifikan terhadap ROE. Pembiayaan dengan akad murabahah paling banyak digunakan selain pembiayaan musyarakah, namun dengan resiko yang tidak kecil yakni bila terjadi kredit macet sehingga menimbulkan pengaruh negatif terrhadap ROE. Sesuai dengan teori menurut Purnamasari \& Siwarno (Purnamasari \& Suswinarno, 2011), risiko dalam transaksi murabahah adalah risiko pembiayaan (credit risk) yang disebabkan oleh nasabah wanprestasi atau gagal dalam mengembalikan pembiayaan yang diterima dari bank (default).

\section{Kesimpulan}

Berdasarkan hasil analisis data yang dilakukan maka dapat diambil kesimpulan sebagai berikut: Secara parsial, pembiayaan Mudharabah memiliki pengaruh negatif dan signifikan terhadap profitabilitas BPR Syariah yang diukur dengan ROE. Pengaruh negatif ini dikarenakan resiko dari pembiayaan Mudharabah bila terjadi kerugian akan berdampak pada tingkat pengembalian modal tersebut. Hasil penelitian menunjukkan bahwa pembiayaan Musyarakah berpengaruh positif dan signifikan terhadap profitabilitas BPRS di Indonesia. Hasil tersebut mengindikasikan bahwa setiap kenaikan satu persen berpengaruh terhadap profitabilitas. Sedangkan pembiayaan Murabahah tidak signifikan sehingga tidak berpengaruh terhadap profitabilitas BPR Syariah.Penelitian ini menggunakan analisis regresi data panel dalam menganalisis data. Model estimasi yang terpilih adalah Common Effect. Hasil pengujian menunjukkan bahwa secara simultan pembiayaan Mudharabah, Musyarakah dan Murabahah berpengaruh signifikan terhadap profitabilitas BPRS.

\section{Saran}

Perlu adanya optimalisasi strategi yang dilakukan oleh BPR Syariah dalam meningkatkan profitabilitas bank sehingga dapat meningkatkan pendapatan dan profitabilitas bagi bank.

1. Pada pembiayaan Mudharabah seharusnya ada pengkajian kembali dan lebih dikembangkan sehingga akan menarik minat nasabah dalam bekerjasama, karena akan berpengaruh terhadap pendapatan yang diterima oleh pihak bank. Begitu pula pada pembiayaan Musyarakah, lebih dikembangkan karena karakteristik utama perbankan syariah adalah sistem bagi hasil yang menjadi pembeda dari perbankan konvensional.

2. Pihak bank dalam praktiknya lebih dominan pada pembiayaan Murabahah akan tetapi sebenarnya yang paling beresiko dari pembiayaan yang lain (mudharabah dan musyarakah) adalah pembiayaan mudharabah. Karena bila terjadi risiko kredit macet maka akan mempengaruhi pendapatan dan profitabilitas bank. Sehingga pihak bank lebih berhati-hati dalam memilih nasabah. 


\section{Daftar Pustaka}

Antonio, M. S. (2011). Bank Syariah dari Teori ke Praktek. Depok: Gema Insan dan Tazkia Cendikia.

Ascarya. (2007). Akad dan Produk Bank Syariah. Jakarta: Rajawali Pers.

Davydenko, A. (2011). Determinants of Bank Profitability in Ukraine Determinants of Bank Profitability in Ukraine. Undergraduate Economic Review, 7(1).

Fidin, R. T. (2014). Pengaruh Pembiayaan Musyarakah dan Murabahah Terhadap Profit Perbankan Syariah Di Indonesia. Universitas Muhammadiyyah Surakarta.

Ilmi, M. (2002). Teori dan Praktek Lembaga Mikro Keuangan Syariah (pertama). Yogyakarta: UII Press.

Inti Dwi Permata, R., Yaningwati, F., \& Z.a, Z. (2014). Analisis Pengaruh Pembiayaan Mudharabah dan Musyarakah Terhadap Tingkat Profitabilitas (Return On Equity) (Studi pada Bank Umum Syariah yang terdaftar di Bank Indonesia Periode 2009-2012). Jurnal Administrasi Bisnis, 12(1), 1-9.

Janwari, Y. (2015). Lembaga Keuangan Syariah. (A. Kamsyach, Ed.) (Pertama). Bandung: PT Remaja Rosdakarya.

Kasmir. (2012). Manajemen Perbankan. Jakarta: PT RajaGrafindo Persada.

Kuncoro, M. (2009). Metode Riset untuk Bisnis dan Ekonomi (Ketiga). Jakarta: Erlangga.

Mokni, R. B. S., \& Rachdi, H. (2014). Assessing The Bank Profitability In The MENA Region A Comparative Analysis Between Conventional. International Journal of Islamic and Middle Eastern Finance and Management, 7(3), 305-332. https://doi.org/10.1108/IMEFM-03-2013-0031

OJK. (2016). Statistik Perbankan Syariah - Desember 2015. Yogyakarta: BPFE.

Oktaviana, U. K. F. (2012). Riset Dosen : Financial Ratio to distinguish Islamic Banks, Islamic Business Units and Conventional Banks in Indonesia. (Y. Hidayah, Ed.) (Pertama). Jakarta: Kementrian Agama Republik Indonesia.

Purnamasari, I. D., \& Suswinarno. (2011). Panduan Lengkap Hukum Praktis Populer Kiat-Kiat Cerdas, Mudah, dan bijak Memahami Masalah Akad Syariah (pertama). Bandung: Kaifa.

Reinissa, R. D. (2015). Pengaruh Pembiayaan Mudharabah, Musyarakah, dan Murabahah Terhadap Profitabilitas Bank Syariah Mandiri, Tbk. Jurnal Ilmiah.

Salim, N. J., Mustaffa, R., \& Jusoff, K. (2011). Determinant of Islamic Banking Institutions ' Profitability in Malaysia. World Applied Sciences Journal 12, 12(2010), 1-7.

Syamsudin, L. (2011). Manajemen Keuangan Perusahaan (Konsep Aplikasi dalam Perencanaan, Pengawasan, dan Pengambilan Keputusan) Edisi Baru. Jakarta: PT RajaGrafindo Persada.

Umam, K. (2011). Legislasi Fikih Ekonomi dan Penerapannya dalam Produk Perbankan Syariah Di Indonesia (Pertama). Yogyakarta: BPFE.

Utomo, Y. P. (2014). Buku Praktet Komputer Statistik II : Eviews. Surakarta: Fakultas Ekonomi dan Bisnis UMS.

Winarno, W. W. (2009). Analisis Ekonometrika dan Statiska dengan EViews (Kedua). Yogyakarta: Unit Penerbit dan Percetakan Sekolah Tinggi Ilmu Manajemen YKPN.

Yuliarmi, N. N., \& Yoga, G. . D. M. (2013). Faktor-Faktor yang Mempengaruhi Penyaluran Kredit BPR di Provinsi Bali. EP Unud, 284-293.

Ziqri, M. (2009). Analisis Pengaruh Pendapatan Murabahah, Mudharabah, dan Musyarakah Terhadap Profitabilitas Bank. Universitas Islam Negeri Syarif Hidayatullah. 